\title{
Altering Physically Effective Fiber Intake Through Forage Proportion and Particle Length: Chewing and Ruminal $\mathrm{pH}^{1}$
}

\author{
W. Z. Yang and K. A. Beauchemin ${ }^{2}$ \\ Agriculture and Agri-Food Canada, Research Centre, Lethbridge, Alberta, T1J 4B1, Canada
}

\begin{abstract}
Alfalfa silages varying in theoretical chop length and diets high and low in forage proportion were used to evaluate whether increasing the physically effective (pe) neutral detergent fiber (NDF) content of dairy cow diets reduces the risk of acidosis. The experiment was designed as a replicated $4 \times 4$ Latin square using 8 ruminally cannulated lactating dairy cows. Treatments were arranged in a $2 \times 2$ factorial design; 2 forage particle lengths (FPL) of alfalfa silage (short and long) were combined with low (35:65) and high (60:40) forage:concentrate $(\mathrm{F}: \mathrm{C})$ ratios [dry matter (DM) basis]. Dietary peNDF content (DM basis) was determined from the sum of the proportion of dietary DM retained on either the 2 sieves ( 8 and $19 \mathrm{~mm}$ ) or the 3 sieves $(1.18,8$, and $19 \mathrm{~mm}$ ) of the Penn State Particle Separator multiplied by the NDF content of the diet. The dietary peNDF contents ranged from 9.6 to $19.8 \%$ using 2 sieves, or from 28.6 to $34.0 \%$ using 3 sieves. Intake of peNDF was increased by increasing both the $\mathrm{F}: \mathrm{C}$ ratio and the FPL of the diets. However, F:C ratio and FPL affected chewing activity differently; increasing $\mathrm{F}: \mathrm{C}$ ratio increased chewing time but increasing FPL only increased chewing when a high-forage diet was fed. Mean ruminal $\mathrm{pH}$ was increased by 0.5 and 0.2 units with increasing $\mathrm{F}: \mathrm{C}$ ratio and FPL, respectively. Cows fed the low F:C diet had $>10$ or $7 \mathrm{~h}$ daily in which ruminal $\mathrm{pH}$ was below 5.8 or 5.5 , respectively, compared with 1.2 and $0.1 \mathrm{~h}$ for cows fed the high F:C ratio diet. Increased F:C ratio reduced ruminal VFA concentration from 135 to 121 $\mathrm{m} M$ but increased the acetate:propionate ratio from 1.82 to 3.13 . Dietary peNDF content when measured using 2 sieves was positively correlated to chewing time $(\mathrm{r}=0.61)$ and mean ruminal $\mathrm{pH}(\mathrm{r}=0.73)$, and negatively correlated to the time that $\mathrm{pH}$ was below 5.8 or $5.5(\mathrm{r}=-0.46)$. This study shows that the risk of ruminal acidosis is high for cows fed a low F:C diet, particularly
\end{abstract}

Received January 16, 2007.

Accepted February 19, 2007.

${ }^{1}$ Contribution number 38707004

${ }^{2}$ Corresponding author: beauchemink@agr.gc.ca when finely chopped silage is used. Intake of dietary peNDF is a good indicator of ruminal $\mathrm{pH}$ status of dairy cows. Increasing the proportion of forage in the diet helps prevent ruminal acidosis through increased chewing time, a change in meal patterns, and decreased ruminal acid production. Increasing FPL elevates ruminal $\mathrm{pH}$, but in low-forage diets increased FPL does not completely alleviate subacute acidosis because the fermentability of the diet is high and changes in chewing activity are marginal.

Key words: physically effective fiber, chewing, ruminal $\mathrm{pH}$, acidosis

\section{INTRODUCTION}

Subacute ruminal acidosis is a tremendous problem for the dairy industry in terms of lost production efficiency, increased cost of treating sick animals, and reduced cow longevity (Nocek, 1997). Ruminal acidosis occurs when the $\mathrm{pH}$ in the rumen declines below optimum for fiber digestion by the rumen bacteria (Owens et al., 1998). Low ruminal $\mathrm{pH}$ is the result of an accumulation of VFA due to feeding diets containing high proportions of fermentable concentrates combined with the use of forages with low physically effective fiber content (Beauchemin et al., 2003).

Physically effective NDF (peNDF) measures the physical characteristics of fiber by accounting for particle length and NDF content, which promote chewing and the flow of salivary buffers to the rumen (Mertens, 1997). The term peNDF is used in diet formulation to provide fiber of adequate particle length to reduce acidosis. A number of studies have been conducted recently to determine the effects of peNDF on chewing activity and ruminal $\mathrm{pH}$ in dairy cows (Krause et al., 2002; Kononoff and Heinrichs, 2003a; Beauchemin and Yang, 2005). However, the responses obtained from these studies have been somewhat inconclusive. In some studies, increased chewing activity as a result of increased peNDF intake increased ruminal $\mathrm{pH}$, helping to minimize ruminal acidosis (Krause et al., 2002; Beauchemin et al., 2003; Yansari et al., 2004), whereas in other studies, peNDF intake was poorly related to chewing activity and ruminal $\mathrm{pH}$ (Kononoff and Hein- 
richs, 2003b; Yang and Beauchemin, 2006a). Chewing activity can increase with increasing intake of peNDF without elevating ruminal $\mathrm{pH}$, particularly when diets contain highly fermentable carbohydrate sources (Kononoff et al., 2003b; Kononoff and Heinrichs, 2003a; Beauchemin and Yang, 2005) because the concept of peNDF does not account for differences in ruminal fermentability of feeds, which can have a major effect on ruminal pH (Yang et al., 2001a; Krause et al., 2002). Beauchemin and Yang (2005) concluded that the effects of dietary peNDF content on chewing activity and rumen function of dairy cows are variable because peNDF content of diets can be increased by increasing the forage proportion of the diet and by increasing the particle length of forages. Increased forage proportion affects intake of fermentable $\mathrm{OM}$ as well as intake of fiber, which could have a significant effect on peNDF requirements. There is little information available documenting the influence of ruminally fermentable carbohydrates on the effects of dietary peNDF levels.

The main objective of this study was to determine the effects of increasing the peNDF content of dairy cow diets on decreasing the risk of acidosis in dairy cows. Dietary peNDF content was varied by adjusting the proportion of forage in the diet and the particle length of silage. We hypothesized that the effects of increased dietary peNDF content depend on the means of increasing dietary peNDF content because forage proportion affects ruminal fermentability of carbohydrates in addition to peNDF, whereas adjusting forage particle length (FPL) only affects peNDF.

\section{MATERIALS AND METHODS}

\section{Alfalfa Silage}

Second-cut, wilted alfalfa silage (AS) was harvested at the early bloom stage of maturity and ensiled in large silo bags (200-t capacity) for 2 mo before being used. A forage harvester (model 6910, John Deere, West Bend, WI), equipped with a 37 -tooth sprocket and 8 knives, was used to obtain silage chopped at a theoretical chop length (TCL) of 7.9 and $19.1 \mathrm{~mm}$ for short and long cut silage, respectively. Two kilograms of each AS (short and long) was obtained weekly and immediately subdivided into 3 portions for determining DM content, particle size, and chemical composition, respectively (Table 1). Particle size distribution of the silage was determined using the Penn State Particle Separator (PSPS; Kononoff and Heinrichs, 2003a) consisting of 3 screens $(19,8$, and $1.18 \mathrm{~mm})$ and a pan. The DM content was determined by oven drying at $55^{\circ} \mathrm{C}$ for $48 \mathrm{~h}$. The third portion of the samples was composited by experimental period and retained for determination of chemical composition. Fermentation characteristics of the silage
Table 1. Chemical composition and particle length of alfalfa silage

\begin{tabular}{|c|c|c|c|c|}
\hline \multirow[b]{2}{*}{ Item } & \multicolumn{2}{|c|}{ Alfalfa silage $^{1}$} & \multirow[b]{2}{*}{$\mathrm{SE}$} & \multirow[b]{2}{*}{$P<$} \\
\hline & $\begin{array}{c}\text { Short } \\
\text { cut }\end{array}$ & $\begin{array}{l}\text { Long } \\
\text { cut }\end{array}$ & & \\
\hline \multicolumn{5}{|l|}{ Chemical composition } \\
\hline DM, \% & 54.9 & 51.1 & 1.1 & 0.01 \\
\hline $\mathrm{OM}, \%$ of $\mathrm{DM}$ & 89.3 & 89.3 & 0.2 & $\mathrm{NS}^{2}$ \\
\hline $\mathrm{NDF}, \%$ of $\mathrm{DM}$ & 44.7 & 46.2 & 0.5 & 0.03 \\
\hline $\mathrm{ADF}, \%$ of $\mathrm{DM}$ & 37.1 & 35.9 & 0.6 & 0.01 \\
\hline $\mathrm{CP}, \%$ of $\mathrm{DM}$ & 21.1 & 21.3 & 0.3 & NS \\
\hline \multicolumn{5}{|c|}{ Particle length determinations ${ }^{3}$} \\
\hline$\%$ of $\mathrm{DM}$ retained on & & & & \\
\hline $19.0 \mathrm{~mm}$ & 12.8 & 23.6 & 1.4 & 0.01 \\
\hline $8.0 \mathrm{~mm}$ & 40.6 & 48.8 & 0.8 & 0.01 \\
\hline $1.18 \mathrm{~mm}$ & 42.1 & 23.2 & 1.0 & 0.01 \\
\hline Pan & 4.6 & 4.4 & 0.2 & NS \\
\hline $\operatorname{pef}_{80}$ & 53.3 & 72.4 & 1.2 & 0.01 \\
\hline pef $_{1.18}$ & 95.4 & 95.6 & 0.2 & NS \\
\hline $\mathrm{peNDF}_{8.0}, \%$ of $\mathrm{DM}$ & 23.9 & 33.5 & 0.6 & 0.01 \\
\hline peNDF $_{1.18}, \%$ of DM & 42.7 & 44.2 & 0.5 & 0.03 \\
\hline
\end{tabular}

${ }^{1}$ Alfalfa forage was harvested at a theoretical chop length of 19.1 or $7.9 \mathrm{~mm}$ for long- or short-cut silages, respectively. Fermentation variables were short and long cut, respectively, 4.90 and 4.74 for $\mathrm{pH}$; 1.49 and $1.90 \%$ of DM for acetic acid; 4.7 and $7.4 \%$ of DM for lactic acid; and 2.2 and $2.0 \%$ of DM for ammonia.

${ }^{2} \mathrm{NS}=P>0.10$.

${ }^{3}$ Particle length variables were measured using the Penn State Particle Separator (Kononoff et al., 2003a); pef $_{8.0}$ and pef $_{1.18}=$ physical effectiveness factor determined as the proportion of particles retained on 2 sieves (Lammers et al., 1996) and on 3 sieves (Kononoff et al., 2003a), respectively; peNDF ${ }_{8.0}$ and peNDF $1.18=$ physically effective $\mathrm{NDF}$ determined as NDF content of alfalfa silage multiplied by pef $f_{8.0}$ and pef $_{1.18}$, respectively.

were determined commercially by Cumberland Valley Analytical Service, Inc. (Maugamsville, MD) with a single representative sample from the silo before starting the experiment.

\section{Cows and Diets}

Eight ruminally cannulated lactating cows were used in an experiment designed as a replicated $4 \times 4$ Latin square with a $2 \times 2$ factorial arrangement of treatments for measuring intake, chewing activity, and ruminal $\mathrm{pH}$ and fermentation characteristics. The ruminal cannulas measured $10 \mathrm{~cm}$ in diameter and were constructed of soft plastic (Bar Diamond, Parma, ID). Cows were housed in individual tie stalls and offered a TMR 3 times daily at 0600,1500 , and $1800 \mathrm{~h}$ for ad libitum intake. Cows, averaging $628 \pm 55 \mathrm{~kg}$ of BW and $65 \pm$ 20 DIM, were cared for according to the Canadian Council on Animal Care Guidelines (Ottawa, Ontario, Canada).

Cows were offered 1 of 4 diets that consisted of the short and long AS, combined with low (35:65) and high (60:40) forage:concentrate $(\mathbf{F}: \mathbf{C})$ ratios (DM basis; Table 2). Thus, intake of peNDF was increased through FPL and proportion of forage in the diet. The peNDF con- 
Table 2. Ingredients and chemical composition of the diets (DM basis)

\begin{tabular}{|c|c|c|c|c|}
\hline \multirow[b]{3}{*}{ Ingredients, \% } & \multicolumn{4}{|c|}{ Forage:concentrate $(\mathrm{F}: \mathrm{C})^{1}$} \\
\hline & \multicolumn{2}{|c|}{$35: 65$} & \multicolumn{2}{|c|}{$60: 40$} \\
\hline & Short & Long & Short & Long \\
\hline Alfalfa silage, short cut & 35.7 & - & 59.5 & — \\
\hline Alfalfa silage, long cut & - & 35.7 & - & 59.5 \\
\hline Barley grain, steam-rolled ${ }^{2}$ & 56.1 & 56.1 & 31.1 & 31.1 \\
\hline Corn gluten meal & 3.33 & 3.33 & 3.33 & 3.33 \\
\hline Canola meal (Alberta Gold) ${ }^{3}$ & 1.43 & 1.43 & 1.19 & 1.19 \\
\hline Soypass $^{4}$ & 1.43 & 1.43 & 1.19 & 1.19 \\
\hline Beet molasses & 0.48 & 0.48 & 0.95 & 0.95 \\
\hline Calcium carbonate & 0.24 & 0.24 & 0.24 & 0.24 \\
\hline Dicalcium phosphorus & 0.24 & 0.24 & 0.24 & 0.24 \\
\hline Monosodium phosphate & 0.05 & 0.05 & 0.05 & 0.05 \\
\hline Vitamin-mineral mix ${ }^{5}$ & 0.71 & 0.71 & 0.71 & 0.71 \\
\hline Canola oil & 0.19 & 0.19 & 0.48 & 0.48 \\
\hline Megalac (Enertia) ${ }^{6}$ & - & - & 0.95 & 0.95 \\
\hline Binding agent $(\mathrm{Aka})^{7}$ & 0.11 & 0.11 & 0.12 & 0.12 \\
\hline Flavoring agent & 0.01 & 0.01 & 0.01 & 0.01 \\
\hline
\end{tabular}

${ }^{1}$ Alfalfa forage was harvested at a theoretical chop length of 19.1 or $7.9 \mathrm{~mm}$ for long- and short-cut silages, respectively. Diets were formulated using the NRC model (2001).

${ }^{2}$ Chemical composition of barley grain (DM basis) was $97.7 \%$ for OM; $20.8 \%$ for NDF; $7.2 \%$ for $\mathrm{ADF}$; and $12.4 \%$ for $\mathrm{CP}$.

${ }^{3}$ Heat-processed canola meal product (Canbra Foods, Lethbridge, Alberta, Canada).

${ }^{4}$ Cargill (Des Moines, IA).

${ }^{5}$ Contained $58.8 \% \mathrm{NaCl}, 16.0 \%$ Dynamate (Pitman Moore, Inc., Mundelein, IL; $18 \% \mathrm{~K}, 11 \% \mathrm{Mg}, 22 \% \mathrm{~S}, 1,000 \mathrm{mg}$ of $\mathrm{Fe} / \mathrm{kg}$ ), $2 \%$ $\mathrm{ZnSO}_{4} \cdot \mathrm{H}_{2} \mathrm{O}, 2.4 \% \mathrm{MnSO}_{4} \cdot 4 \mathrm{H}_{2} \mathrm{O}, 0.01 \% \mathrm{CoSO}_{4} \cdot 6 \mathrm{H}_{2} \mathrm{O}, 0.009 \% \mathrm{Na}_{2}$ $\mathrm{SeO}_{3}, 0.012 \%$ ethylenediamine dihydroiodide, $0.8 \% \mathrm{CuSO}_{4} \cdot 5 \mathrm{H}_{2} \mathrm{O}$, $2,000,000 \mathrm{IU} / \mathrm{kg}$ of vitamin A, 200,000 IU/kg of vitamin D, and 2,000 $\mathrm{IU} / \mathrm{kg}$ of vitamin $\mathrm{E}$.

${ }^{6} \mathrm{ADM}$ Animal Health \& Nutrition (Quincy, IL).

${ }^{7}$ Bear River Zeolite of Canada Corp. (Lethbridge, Alberta, Canada).

tents ranged from 9.6 to $19.8 \% \mathrm{DM}$ and 28.6 to $34.0 \%$ DM determined using the PSPS with 2 sieves ( $\mathbf{p e N D F}_{\mathbf{8 . 0}}$ ) or 3 sieves (peNDF 1.18 ), respectively (Table 3 ). The diets were formulated using the NRC model (2001) to supply sufficient energy and protein for a 650$\mathrm{kg}$ cow to produce $35 \mathrm{~kg} / \mathrm{d}$ of milk containing $3.5 \%$ fat and $3.2 \%$ protein.

Each period consisted of $13 \mathrm{~d}$ of adaptation to diets and $8 \mathrm{~d}$ of experimental measurements. Feed offered and orts were measured and recorded daily during the last 8-d of the period to calculate feed intake. Feed samples including AS and TMR were collected once weekly, and orts were collected daily and composited weekly for particle length and DM determination. Samples were then composited by period, dried in an oven at $55^{\circ} \mathrm{C}$ for $48 \mathrm{~h}$, and then ground through a $1-\mathrm{mm}$ diameter screen (standard model 4, Arthur H. Thomas Co., Philadelphia, PA) for analysis of OM, NDF, ADF, starch, and CP. Milk production was recorded daily, morning and evening, and sampled on 5 consecutive days during the last 10-d of the period for milk fat, CP, and lactose determination using an infrared analyzer (MilkoScan 605, Foss Electric, Hillerød, Denmark).

\section{Meal Duration and Feeding Behavior}

Feeding behavior was monitored for $48 \mathrm{~h}$ on $\mathrm{d} 14$ to 16 of the period. Mangers attached to load cells (Omega Engineering Inc., Stamford, CT) and connected to a computer were used to measure the feed weight over time. An average weight was obtained every $11 \mathrm{~s}$ and stored using Collect software (Labtronics, Inc., Guelph, Ontario, Canada). During feeding activity, the weight of the manger decreased. Feeding activity was separated into meals using a meal criterion of $27 \mathrm{~min}$ as outlined by DeVries et al. (2003). A meal criterion is the minimum time interval between 2 meals and is used to determine meal frequency and meal duration. A meal was defined as eating activity $>30 \mathrm{~s}$ and $>300 \mathrm{~g}$ of feed being removed from the feeder. Rate of DMI was calculated as the ratio of DM ingested and duration of the meal.

\section{Chewing Activity}

Chewing activity was measured concurrently with feeding behavior. Cows were fitted for $48 \mathrm{~h}$ with leather halters that measured jaw movements. Each halter contained a piezo disk (Edmund Scientific Company, Barrington, $\mathrm{NJ}$ ), which was inserted within the halter and positioned under the jaw. The chewing action places stress on the disk generating an electrical signal, which is then processed and counted as a single jaw movement. A datalogger (Campbell Scientific Inc., Logan, UT) was used to receive the output signal from each cow. The number of jaw movements was summed each minute and stored for subsequent analysis. The jaw movements were then designated as eating or ruminating chews based on several criteria. Jaw movements were considered as eating chews if they occurred during a meal (i.e., duration of the eating activity was $>30 \mathrm{~s}$ and $>300 \mathrm{~g}$ of feed was removed from the feeder during the meal). Jaw movements were designated as ruminating chews if they did not occur during a meal and rate of chewing exceeded 30 chews $/ \mathrm{min}$. All other jaw movements were considered to be associated with licking, drinking, and grooming and were not included in the eating or ruminating categories. Total number of chews was calculated as the sum of eating and ruminating chews. Total time spent eating, ruminating, and chewing (eating + ruminating) was based on the duration of each chewing activity.

\section{Ruminal $\mathrm{pH}$ and Fermentation}

Ruminal $\mathrm{pH}$ was monitored for $48 \mathrm{~h}$ concurrent with measurements of feeding behavior and chewing activ- 
Table 3. Physical and chemical composition of the diets ${ }^{1}$

\begin{tabular}{|c|c|c|c|c|c|c|c|c|}
\hline \multirow[b]{3}{*}{ Item } & \multicolumn{4}{|c|}{ Forage:concentrate (F:C) } & \multirow[b]{3}{*}{$\mathrm{SE}$} & \multirow{2}{*}{\multicolumn{3}{|c|}{ Effect }} \\
\hline & \multicolumn{2}{|c|}{$35: 65$} & \multicolumn{2}{|c|}{$60: 40$} & & & & \\
\hline & Short & Long & Short & Long & & $\mathrm{F}: \mathrm{C}$ & FPL & $\mathrm{F}: \mathrm{C} \times \mathrm{FPL}$ \\
\hline \multicolumn{9}{|l|}{ Physical $^{2}$} \\
\hline \multicolumn{9}{|c|}{$\%$ of DM retained on screens } \\
\hline $19.0 \mathrm{~mm}$ & 3.6 & 7.1 & 7.1 & 13.1 & 0.8 & 0.01 & 0.01 & 0.03 \\
\hline $8.0 \mathrm{~mm}$ & 27.8 & 34.5 & 33.3 & 41.1 & 1.0 & 0.01 & 0.01 & $\mathrm{NS}^{3}$ \\
\hline $1.18 \mathrm{~mm}$ & 63.0 & 52.8 & 52.9 & 39.1 & 0.8 & 0.01 & 0.01 & 0.01 \\
\hline Pan & 5.6 & 5.7 & 6.6 & 6.7 & 0.3 & 0.01 & NS & NS \\
\hline $\operatorname{pef}_{8.0}$ & 31.4 & 41.5 & 40.4 & 54.2 & 0.9 & 0.01 & 0.01 & 0.03 \\
\hline pef $_{1.18}$ & 94.4 & 94.3 & 93.4 & 93.3 & 0.3 & 0.01 & NS & NS \\
\hline peNDF $_{8.0}, \%$ & 9.6 & 12.7 & 13.9 & 19.8 & 0.6 & 0.01 & 0.01 & 0.03 \\
\hline $\operatorname{peNDF}_{1.18}, \%$ & 28.6 & 28.8 & 32.2 & 34.0 & 0.9 & 0.01 & NS & NS \\
\hline \multicolumn{9}{|l|}{ Chemical } \\
\hline $\mathrm{DM}, \%$ & 72.5 & 71.1 & 66.0 & 62.0 & 1.4 & 0.01 & 0.02 & NS \\
\hline $\mathrm{OM}, \%$ of DM & 93.4 & 93.1 & 91.2 & 90.9 & 0.2 & 0.01 & NS & NS \\
\hline $\mathrm{CP}, \%$ of $\mathrm{DM}$ & 19.9 & 20.5 & 21.6 & 21.8 & 0.4 & 0.01 & NS & NS \\
\hline $\mathrm{NDF}, \%$ of $\mathrm{DM}$ & 30.3 & 30.6 & 34.5 & 36.4 & 0.9 & 0.01 & NS & NS \\
\hline Forage NDF, $\%$ of DM & 16.0 & 16.5 & 26.6 & 27.5 & 0.2 & 0.01 & 0.01 & NS \\
\hline NDF from forage, $\%$ & 53.0 & 54.0 & 77.2 & 75.6 & 1.9 & 0.01 & NS & NS \\
\hline $\mathrm{ADF}, \%$ of $\mathrm{DM}$ & 20.4 & 21.6 & 26.9 & 27.4 & 0.5 & 0.01 & 0.06 & NS \\
\hline Starch, \% of DM & 30.6 & 30.6 & 17.8 & 17.8 & 0.8 & 0.01 & NS & NS \\
\hline RUP, \% of CP & 35.2 & 35.2 & 33.5 & 33.5 & - & - & - & - \\
\hline $\mathrm{NE}_{\mathrm{L}}, \mathrm{Mcal} / \mathrm{kg}$ & 1.65 & 1.65 & 1.65 & 1.65 & - & - & - & - \\
\hline
\end{tabular}

${ }^{1} \mathrm{FPL}=$ forage particle length; alfalfa forage was harvested at a theoretical chop length of 19.1 and 7.9 $\mathrm{mm}$ for long- and short-cut silages, respectively.

${ }^{2}$ Particle size distribution of TMR was measured using the Penn State Particle Separator (Kononoff et al., 2003a); pef $f_{8.0}$ and pef $f_{1.18}=$ physical effectiveness factor determined as the proportion of particles retained on 2 sieves (Lammers et al., 1996) and on 3 sieves (Kononoff et al., 2003a), respectively; peNDF 8.0 $_{8}$ and peNDF $_{1.18}=$ physically effective NDF determined as NDF content of TMR multiplied by pef ${ }_{8.0}$ and pef 1.18, $_{\text {, }}$ respectively.

${ }^{3} \mathrm{NS}=P>0.10$.

ity. The $\mathrm{pH}$ was measured using an industrial electrode (model S650-CDHF, Sensorex, Garden Grove, CA) linked to a $\mathrm{pH}$ controller (model PHCN-37, Omega Engineering Inc.) as described in detail by Penner et al. (2006). The electrodes were suspended approximately $60 \mathrm{~cm}$ in the rumen using a cable that was anchored to the ruminal cannula plug. The electrode was weighted down to ensure submersion within the rumen contents. This indwelling continuous ruminal $\mathrm{pH}$ measurement device results in values that are about 0.05 units lower than manual measurements of $\mathrm{pH}$ taken from the same location within the rumen (Penner et al., 2006). The electrodes were covered with a perforated guard to prevent them from coming into direct contact with the rumen wall. The $\mathrm{pH}$ electrodes were removed from the rumen for 20 min daily between 1400 and $1430 \mathrm{~h}$ for calibration using pH 4.0 and 7.0 standards. Continuous measurements from the indwelling probe were sent to a datalogger (Campbell Scientific Inc.) every $5 \mathrm{~s}$ and averaged every $5 \mathrm{~min}$. Ruminal $\mathrm{pH}$ data were summarized daily for each cow as mean, minimum, and maximum $\mathrm{pH}$, area between the observed $\mathrm{pH}$ and a line drawn at $\mathrm{pH} 5.8$ or 5.5 , and time (h) under $\mathrm{pH} 5.8$ or 5.5. The minimum and maximum $\mathrm{pH}$ value for each day and each cow was obtained from the raw input data using PROC MEANS (SAS Institute, 1996). The area was calculated by adding the absolute value of negative deviations in $\mathrm{pH}$ from 5.5 or 5.8 for each 5 -min interval. A ruminal $\mathrm{pH}$ of 5.8 was chosen as a benchmark because the corresponding loss in fiber digestion below this $\mathrm{pH}$ threshold has negative effects on milk production. The $\mathrm{pH}$ of 5.5 was used to further categorize subclinical ruminal acidosis in terms of its severity.

Ruminal fluid was collected on d 17 at 0900, 1300, and $1600 \mathrm{~h}$ from multiple sites in the rumen for VFA and $\mathrm{NH}_{3}-\mathrm{N}$ determination. Samples were immediately squeezed through 4 layers of cheesecloth with a mesh size of $250 \mu \mathrm{m}$. Five milliliters of filtrate was preserved by adding $1 \mathrm{~mL}$ of $25 \% \mathrm{HPO}_{3}$ and used to determine VFA, and $5 \mathrm{~mL}$ of filtrate was preserved by adding 1 $\mathrm{mL}$ of $1 \% \mathrm{H}_{2} \mathrm{SO}_{4}$ and used to determine $\mathrm{NH}_{3}-\mathrm{N}$. The samples were subsequently stored frozen at $-20^{\circ} \mathrm{C}$ until analyzed.

\section{Chemical Analyses}

Feed DM was determined by oven drying at $55^{\circ} \mathrm{C}$ for $48 \mathrm{~h}$. Analytical DM content of the samples was 
determined by drying at $135^{\circ} \mathrm{C}$ for $3 \mathrm{~h}$ (AOAC, 1990). The OM content was calculated as the difference between DM and ash contents, with ash determined by combustion at $550^{\circ} \mathrm{C}$ overnight. The NDF and $\mathrm{ADF}$ contents were determined using the methods described by Van Soest et al. (1991) with amylase and sodium sulfite used in the NDF procedure. Starch was determined by enzymatic hydrolysis of $\alpha$-linked glucose polymers as described by Rode et al. (1999). Content of $\mathrm{N}$ in the samples was determined by flash combustion (model 1500; Carlo Erba Instruments, Milan, Italy). Ruminal VFA were separated and quantified by gas chromatography (Varian 3700; Varian Specialties Ltd., Brockville, Ontario, Canada) using a $15-\mathrm{m}$ (0.53-mm i.d.) fused silica column (DB-FFAP column; J\&W Scientific, Folsom, CA). The ammonia content of ruminal samples was determined using the method described by Weatherburn (1967) modified to use a plate reader. Particle size distributions of AS and TMR were determined using the PSPS. Physical effectiveness factors (pef) for silage and TMR were calculated as the sum of the proportion of DM retained on 2 screens: 19 and $8 \mathrm{~mm}$

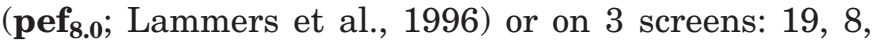
and $1.18 \mathrm{~mm}$ (pef 1.18; $_{1 .}$ Kononoff et al., 2003a). The peNDF $_{8.0}$ and peNDF 1.18 contents of the AS and TMR were calculated by multiplying NDF content of the feed by the pef $_{8.0}$ and pef ${ }_{1.18}$, respectively.

\section{Calculations and Statistical Analyses}

Data for feeding behavior, chewing activity, and ruminal $\mathrm{pH}$ were summarized by day and analyzed using the mixed model procedure of SAS (PROC MIXED; SAS Institute, 1996). The model included treatments (FPL and $\mathrm{F}: \mathrm{C}$ ) and the interaction between FPL and F:C as a fixed effect and square, period within square, and cow within square as random effects with day included as a repeated measure using compound symmetry. Estimation method was restrictive maximum likelihood (REML) and the degrees of freedom method was Kenward-Rogers. Similarly, data for VFA and ammonia were analyzed by sampling time using repeated measures techniques. Data for particle distribution, pef and peNDF of forages and diets were averaged by period and analyzed by including particle length variables as fixed effects and period as a random effect. Pearson correlation coefficients were estimated using the CORR procedure of SAS. Effects of the factors were declared significant at $P<0.05$ unless otherwise noted and trends were discussed at $P<0.10$.

\section{RESULTS}

\section{Particle Length and Physically Effective Fiber}

Particle length variables and measures of peNDF content differed for the 2 AS cuts as expected (Table
1). The proportion of particles retained on the 8-and 19-mm sieves increased as the TCL of AS was increased from 7.9 to $19.1 \mathrm{~mm}$, and as a result, pef $_{8.0}$ and peNDF $\mathrm{N}_{8.0}$ were increased by up to $40 \%$. Changes in pef $_{1.18}$ and peNDF $_{1.18}$ were minimal because increased proportion of long particles $(19 \mathrm{~mm}$ ) was compensated for by reduced proportion of short particles $(1.18 \mathrm{~mm})$.

Low and high F:C diets differed in chemical composition as expected (Table 3). In addition, increased F:C ratio increased the proportion of particles on the 19and 8-mm sieves, pef $_{8.0}$, peNDF $_{8.0}$, and peNDF $_{1.18}$, but decreased the proportion of particles on the $1.18-\mathrm{mm}$ sieve and pef ${ }_{1.18}$. Increased dietary FPL increased the proportion of particles on 19- and 8-mm sieves, and pef $_{8.0}$ and content of peNDF 8.0 . However, contents of pef $_{1.18}$ and peNDF 1.18 were not affected by the dietary FPL because the proportion of particles retained on the $1.18-\mathrm{mm}$ sieve was reduced with increasing dietary FPL.

Thus, measuring pef and peNDF using 3 sieves was insensitive to changes in proportion of forage and FPL. There were interactions between F:C and FPL for proportion of particles on the 19- and 1.18-mm sieves, pef $_{8.0}$, and peNDF $_{8.0}$; pef and peNDF measured using 2 sieves were all increased to a greater extent by increasing FPL of the high F:C diet compared with increasing the FPL of a low F:C diet, which reflected the difference in silage proportion between these 2 diets.

\section{Intake, Milk Production, and Composition}

Increased $\mathrm{F}: \mathrm{C}$ ratio decreased DMI but increased intake of NDF (Table 4), whereas intakes of DM and NDF were not affected by FPL. The effects of increasing FPL on intake of peNDF ${ }_{8.0}$ depended upon $\mathrm{F}: \mathrm{C}$ ratio; the increase in peNDF ${ }_{8.0}$ intake with increasing FPL was greater for the high F:C diet $(58 \%)$ than for the low $\mathrm{F}: \mathrm{C}$ diet $(35 \%)$. Actual milk yield were decreased with increasing F:C ratio. Content of milk fat was increased, whereas contents of milk protein and milk lactose were decreased with increasing $\mathrm{F}: \mathrm{C}$ ratio. Milk production and composition were not affected by the FPL.

\section{Chewing Activity and Meal Patterns}

Eating activity, expressed as number of chews or minutes per unit of DMI, was increased with increasing dietary F:C ratio (Table 5). However, FPL did not affect eating activity. Increasing the proportion of $\mathrm{F}: \mathrm{C}$ also increased number of ruminating chews (chews/d and chews/kg of DMI) and ruminating time per unit of DMI, but FPL only increased these variables when the proportion of forage in the diet was high. The amount of rumination promoted per unit of peNDF ${ }_{1.18}$ was consis- 
Table 4. Effects of forage-to-concentrate ratio (F:C) and forage particle length (FPL) on feed intake, milk yield, and composition ${ }^{1}$

\begin{tabular}{|c|c|c|c|c|c|c|c|c|}
\hline \multirow[b]{3}{*}{ Item } & \multicolumn{4}{|c|}{$\mathrm{F}: \mathrm{C}$} & \multirow[b]{3}{*}{$\mathrm{SE}$} & \multirow{2}{*}{\multicolumn{3}{|c|}{ Effect }} \\
\hline & \multicolumn{2}{|c|}{$35: 65$} & \multicolumn{2}{|c|}{$60: 40$} & & & & \\
\hline & Short & Long & Short & Long & & $\mathrm{F}: \mathrm{C}$ & FPL & $\mathrm{F}: \mathrm{C} \times \mathrm{FPL}$ \\
\hline \multicolumn{9}{|l|}{ DMI } \\
\hline $\mathrm{kg} / \mathrm{d}$ & 23.8 & 23.9 & 21.6 & 21.9 & 3.4 & 0.01 & $\mathrm{NS}^{2}$ & NS \\
\hline$\%$ of BW & 3.64 & 3.71 & 3.43 & 3.42 & 0.17 & 0.01 & NS & NS \\
\hline NDF intake, $\mathrm{kg} / \mathrm{d}$ & 7.0 & 7.1 & 7.2 & 7.9 & 1.1 & 0.05 & NS & NS \\
\hline $\mathrm{peNDF}_{8.0}{ }^{3}$ intake, $\mathrm{kg} / \mathrm{d}$ & 2.0 & 2.7 & 2.6 & 4.1 & 0.5 & 0.01 & 0.01 & 0.05 \\
\hline peNDF $_{1.18}{ }^{3}$ intake, $\mathrm{kg} / \mathrm{d}$ & 6.6 & 6.7 & 6.7 & 7.3 & 1.1 & NS & NS & NS \\
\hline $\mathrm{BW}, \mathrm{kg}$ & 652 & 644 & 630 & 636 & 64 & 0.01 & NS & 0.05 \\
\hline Actual milk yield, $\mathrm{kg} / \mathrm{d}$ & 33.1 & 33.4 & 30.2 & 30.5 & 4.5 & 0.01 & NS & NS \\
\hline $\begin{array}{l}\text { Milk composition, \% } \\
\text { Fat }\end{array}$ & 3.33 & 3.33 & 3.73 & 3.64 & 0.17 & 0.01 & NS & NS \\
\hline Protein & 3.28 & 3.31 & 3.02 & 3.02 & 0.08 & 0.01 & NS & NS \\
\hline Lactose & 4.65 & 4.66 & 4.61 & 4.59 & 0.07 & 0.05 & NS & NS \\
\hline
\end{tabular}

tent among diets, whereas rumination per unit of peNDF $_{8.0}$ intake varied with F:C and FPL. Total chewing (eating + ruminating) measured as number of chews (/d and $/ \mathrm{kg}$ of $\mathrm{DM}$ ) and chewing time ( $\mathrm{min} / \mathrm{d}$ and $\mathrm{min} /$ $\mathrm{kg}$ of $\mathrm{DM}$ ) increased or tended to increase with increasing F:C. This increase was due to increased NDF intake, because chews per kilogram of NDF and minutes per kilogram of NDF were constant among diets. Thus, increasing the proportion of forage in the diet increased chewing activity due to the increase in NDF consumed. The effects of FPL on chewing activity depended upon F:C; increasing FPL only increased chewing (chews/kg of DM and $\mathrm{min} / \mathrm{kg}$ of DM) when diets contained a high proportion of forage. In addition, each unit of peNDF $\mathrm{F}_{8.0}$ was more effective in promoting chewing in low-forage diets containing short-chopped silages. Total chewing time per unit of peNDF 8.0 intake was decreased by 74 or $94 \mathrm{~min}$, respectively, with increasing $\mathrm{F}: \mathrm{C}$ ratio or FPL. However, chewing time per unit of peNDF ${ }_{1.18}$ intake was constant across the treatments.

Pattern of diurnal eating activity of cows was similar among the treatments (Figure 1). The highest eating activity was observed after the $1500 \mathrm{~h}$ feeding followed by activity at the $0600 \mathrm{~h}$ feeding. However, cows did not exhibit peak eating activity at the third feeding $(1800 \mathrm{~h})$ due to high eating activity between 1500 and 1700 h. Ruminating time was equally distributed throughout the day except during eating time. Cows fed a high F:C consumed more meals per day of smaller size ( $\mathrm{kg}$ of $\mathrm{DM} / \mathrm{meal}$ ) with slower eating rate than cows fed low F:C diets (Table 5). Meal pattern was not affected by dietary FPL.

\section{Ruminal $\mathrm{pH}$ and Fermentation}

Diurnal ruminal $\mathrm{pH}$ for all treatments was highest just before the 0600 and $1500 \mathrm{~h}$ feedings (Figure 2). Diurnal variation in ruminal $\mathrm{pH}$ was greater for the low $\mathrm{F}$ : $\mathrm{C}$ diet than for the high $\mathrm{F}: \mathrm{C}$ diet, especially when low F:C was combined with long FPL. For example, between 1400 and $2100 \mathrm{~h}$, the average hourly $\mathrm{pH}$ declined by 0.8 units (from 6.3 to 5.5) for cows fed low F:C combined with long FPL, whereas $\mathrm{pH}$ for cows on the other diets dropped 0.42 to 0.49 units during this time. Mean, minimum, and maximum ruminal $\mathrm{pH}$, area between the curve and a horizontal line at $\mathrm{pH} 5.8$ or 5.5 , and duration that $\mathrm{pH}<5.8$ or $\mathrm{pH}<5.5$ were elevated by increasing $\mathrm{F}: \mathrm{C}$ ratio (Table 6 ). Increased dietary FPL increased only mean and maximum ruminal $\mathrm{pH}$. There was a numerical $(P<0.11)$ interaction between $\mathrm{F}$ : $\mathrm{C}$ and FPL for mean ruminal $\mathrm{pH}$; increasing $\mathrm{F}$ : $\mathrm{C}$ ratio increased mean ruminal $\mathrm{pH}$ to a greater extent when dietary FPL was short ( 0.60 units) compared with when dietary FPL was long (0.38 units) and increasing FPL increased ruminal $\mathrm{pH}$ to a greater extent with low $\mathrm{F}: \mathrm{C}$ diets (0.31 units) vs. high F:C diets (0.09 units).

Increasing the $\mathrm{F}: \mathrm{C}$ decreased the fermentability of the diet, whereas FPL had very little effect on rumen fermentation (Table 6). Increasing the F:C ratio decreased total concentration of VFA, increased the molar proportion of acetate and branched-chain VFA, decreased the proportion of propionate, and increased the molar proportion of ammonia.

\section{DISCUSSION}

Physically effective fiber combines measures of the chemical and physical characteristics of fiber. In this 
Table 5. Effects of forage-to-concentrate ratio (F:C) and forage particle length (FPL) on chewing activity of lactating dairy cows ${ }^{1}$

\begin{tabular}{|c|c|c|c|c|c|c|c|c|}
\hline \multirow[b]{3}{*}{ Item } & \multicolumn{4}{|c|}{$\mathrm{F}: \mathrm{C}$} & \multirow[b]{3}{*}{ SE } & \multirow{2}{*}{\multicolumn{3}{|c|}{ Effect }} \\
\hline & \multicolumn{2}{|c|}{$35: 65$} & \multicolumn{2}{|c|}{$60: 40$} & & & & \\
\hline & Short & Long & Short & Long & & $\mathrm{F}: \mathrm{C}$ & FPL & $\mathrm{F}: \mathrm{C} \times \mathrm{FPL}$ \\
\hline \multicolumn{9}{|l|}{ Eating } \\
\hline Chews/d & 11,582 & 11,179 & 12,768 & 12,461 & 663 & 0.08 & $\mathrm{NS}^{2}$ & NS \\
\hline Chews/kg of DM & 562 & 529 & 657 & 672 & 30 & 0.01 & NS & NS \\
\hline Chews/kg of NDF & 1,874 & 1,733 & 1,905 & 1,847 & 123 & NS & NS & NS \\
\hline $\operatorname{Min} / \mathrm{d}$ & 202.9 & 210.6 & 225.1 & 218.1 & 9.7 & NS & NS & NS \\
\hline $\mathrm{Min} / \mathrm{kg}$ of $\mathrm{DM}$ & 9.9 & 10.1 & 11.6 & 11.8 & 0.4 & 0.01 & NS & NS \\
\hline $\mathrm{Min} / \mathrm{kg}$ of $\mathrm{NDF}$ & 32.9 & 32.7 & 33.6 & 32.3 & 1.9 & NS & NS & NS \\
\hline $\mathrm{Min} / \mathrm{kg}$ of $\mathrm{peNDF}_{80}{ }^{3}$ & 127.0 & 91.9 & 102.4 & 68.2 & 11.2 & 0.04 & 0.01 & NS \\
\hline $\mathrm{Min} / \mathrm{kg}$ of $\mathrm{peNDF}_{1.18}{ }^{3}$ & 36.7 & 36.7 & 39.3 & 37.5 & $\begin{array}{r}11.4 \\
2.6\end{array}$ & NS & NS & NS \\
\hline \multicolumn{9}{|l|}{ Ruminating } \\
\hline Chews/d & 30,665 & 30,086 & 30,769 & 36,372 & 1775 & 0.04 & 0.09 & 0.05 \\
\hline Chews/kg of DM & 1,500 & 1,425 & 1,586 & 1,977 & 130 & 0.01 & 0.02 & 0.01 \\
\hline Chews/kg of NDF & 5,003 & 4,656 & 4,609 & 5,437 & 433 & NS & NS & 0.03 \\
\hline $\operatorname{Min} / \mathrm{d}$ & 440.8 & 444.0 & 445.5 & 521.7 & 23.2 & NS & NS & NS \\
\hline $\mathrm{Min} / \mathrm{kg}$ of $\mathrm{DM}$ & 21.5 & 21.0 & 23.0 & 28.3 & 1.6 & 0.01 & 0.08 & 0.04 \\
\hline $\mathrm{Min} / \mathrm{kg}$ of $\mathrm{NDF}$ & 71.5 & 68.6 & 66.9 & 77.9 & 5.5 & NS & NS & 0.08 \\
\hline $\mathrm{Min} / \mathrm{kg}$ of $\mathrm{peNDF}_{8.0}{ }^{3}$ & 275.0 & 194.2 & 203.8 & 166.4 & 25.7 & 0.03 & 0.02 & NS \\
\hline $\mathrm{Min} / \mathrm{kg}$ of $\mathrm{peNDF}_{1.18}{ }^{3}$ & 79.6 & 77.3 & 78.1 & 90.1 & 7.6 & NS & NS & NS \\
\hline \multicolumn{9}{|l|}{ Total chewing } \\
\hline Chews/d & 42,247 & 41,265 & 43,536 & 48,833 & 2143 & 0.04 & NS & NS \\
\hline Chews $/ \mathrm{kg}$ of $\mathrm{DM}$ & 2,062 & 1,955 & 2,323 & 2,649 & 151 & 0.01 & 0.03 & 0.01 \\
\hline Chews/kg of NDF & 6,877 & 6,389 & 6,514 & 7,284 & 529 & NS & NS & 0.06 \\
\hline $\operatorname{Min} / \mathrm{d}$ & 643.7 & 654.6 & 670.7 & 739.8 & 27.6 & 0.07 & NS & NS \\
\hline $\mathrm{Min} / \mathrm{kg}$ of DM & 31.3 & 30.9 & 34.6 & 40.1 & 1.9 & 0.01 & 0.07 & 0.05 \\
\hline $\mathrm{Min} / \mathrm{kg}$ of $\mathrm{NDF}$ & 104.1 & 101.3 & 100.5 & 110.2 & 7.0 & NS & NS & NS \\
\hline $\mathrm{Min} / \mathrm{kg}$ of $\mathrm{peNDF}_{8.0}{ }^{3}$ & 401.9 & 286.1 & 306.3 & 234.6 & 36.1 & 0.03 & 0.01 & NS \\
\hline $\mathrm{Min} / \mathrm{kg}$ of $\mathrm{peNDF}_{1.18}{ }^{3}$ & 116.3 & 114.0 & 117.3 & 127.3 & 9.8 & NS & NS & NS \\
\hline \multicolumn{9}{|l|}{ Meal patterns } \\
\hline Meals/d & 8.3 & 8.2 & 9.6 & 10.1 & 0.8 & 0.04 & NS & NS \\
\hline $\mathrm{kg}$ of $\mathrm{DM} / \mathrm{meal}$ & 2.99 & 3.05 & 2.45 & 2.24 & 0.28 & 0.02 & NS & NS \\
\hline $\mathrm{kg}$ of $\mathrm{NDF} / \mathrm{meal}$ & 0.90 & 0.93 & 0.84 & 0.82 & 0.09 & NS & NS & NS \\
\hline Intake rate, $\mathrm{g}$ of $\mathrm{DM} / \mathrm{min}$ & 119.6 & 115.5 & 100.9 & 103.7 & 4.6 & 0.01 & NS & NS \\
\hline
\end{tabular}

${ }^{1}$ Alfalfa forage was harvested at a theoretical chop length of 19.1 and $7.9 \mathrm{~mm}$ for long- and short-cut silages, respectively.

${ }^{2} \mathrm{NS}=P>0.10$.

${ }^{3} \mathrm{peNDF}_{8.0}$ and $\mathrm{peNDF}_{1.18}=$ physically effective NDF determined as NDF content of TMR multiplied by pef $_{8.0}$ and pef 1.18 , respectively (Table 3 ).

study, peNDF intake was increased by increasing the proportion of forage in the diet (i.e., increased NDF content), increasing the particle length of silage (i.e., increased pef content), or both. Measures of peNDF using 2 sieves of the PSPS reflected these dietary changes, whereas measures using 3 sieves of the PSPS were insensitive to changes in F:C and FPL. Increased $\mathrm{F}: \mathrm{C}$ increased peNDF${ }_{8.0}$ intake due to higher pef $\mathrm{f}_{8.0}$ and higher dietary NDF content, whereas increased FPL increased peNDF 8.0 intake only due to increased pef f.0. $_{8 .}$. Even so, increasing the FPL of the low F:C diet resulted in similar peNDF ${ }_{8.0}$ intakes as cows fed a high $\mathrm{F}$ : $\mathrm{C}$ diet using short AS, indicating that chop length of silage can be as important as forage proportion in terms of peNDF intake of cows.

The wide range in particle size distributions of AS and TMR used in our study reflect the variability ob- served on commercial dairy farms. For example, Plaizier et al. (2004) used the PSPS to measure the particle length of AS and TMR from 40 dairy farms across Manitoba, Canada, and found that the particles (proportion by weight) retained on the 19- and $8-\mathrm{mm}$ screens and peNDF content (\% of DM) ranged from 6 to $70 \%, 26$ to $48 \%$, and 15 to $49 \%$, respectively, for AS, and from 3 to $69 \%, 18$ to $50 \%$, and 8 to $37 \%$, respectively, for TMR. The recommended proportions for AS are 10 to $20 \%$ on the $19-\mathrm{mm}$ sieve and 45 to $75 \%$ on the $8-\mathrm{mm}$ sieve, and, for TMR are 2 to $8 \%$ on the $19-\mathrm{mm}$ sieve and 30 to $50 \%$ on the 8-mm sieve (Kononoff and Heinrichs, 2007). These recommendations are based on the assumption that feed particles retained on these sieves promote chewing activity that contributes to rumen buffering. The diets used in our study were within the recommended range, except for the low F:C-short AS diet, 

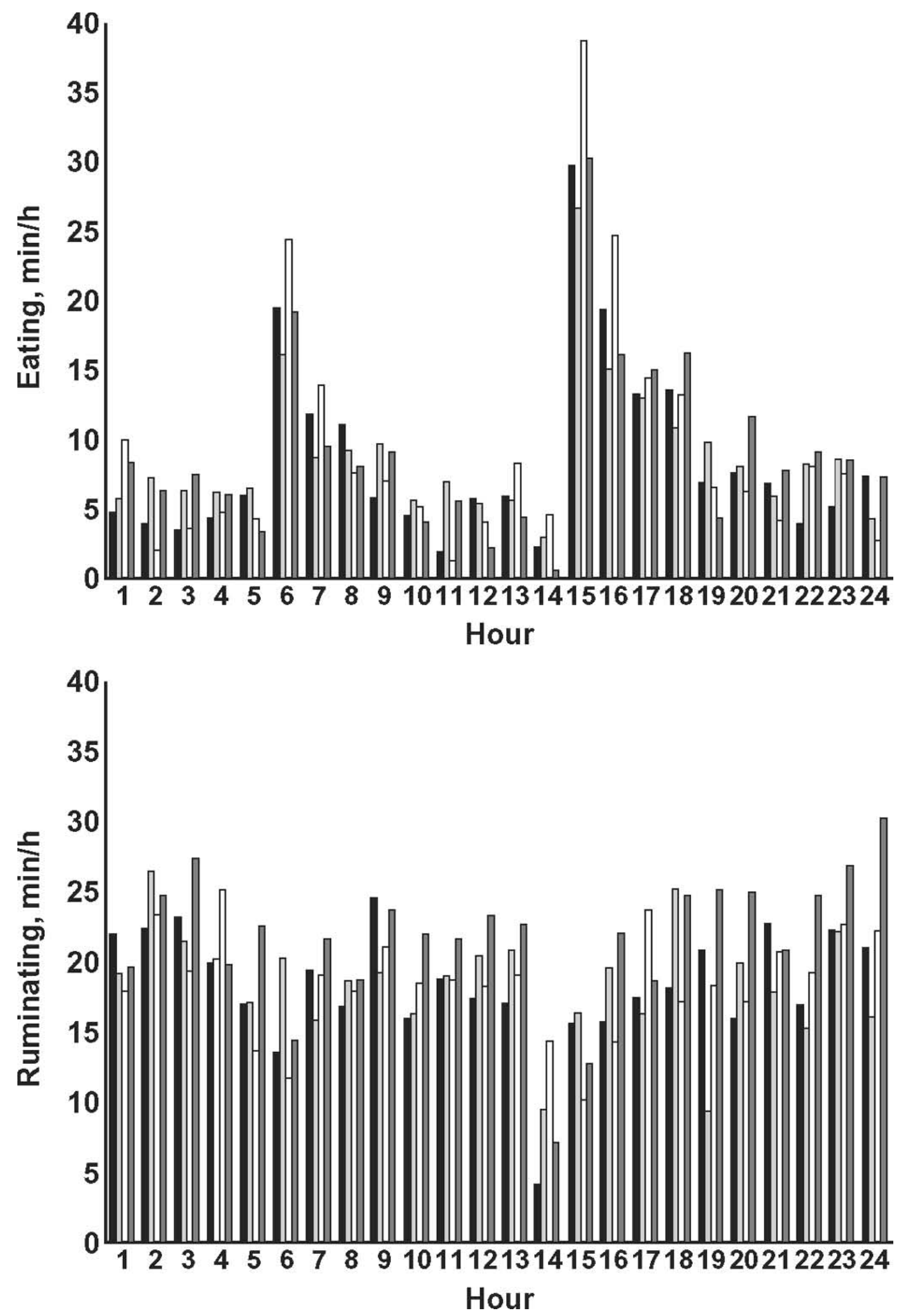

Figure 1. Effects of forage-to-concentrate ratio (low or high) and forage particle length (short or long) on diurnal variation in eating time and ruminating time (low-short, $\mathbf{\square}$; low-long, $\square$; high-short, $\square$; and high-long, $\square$ ). 


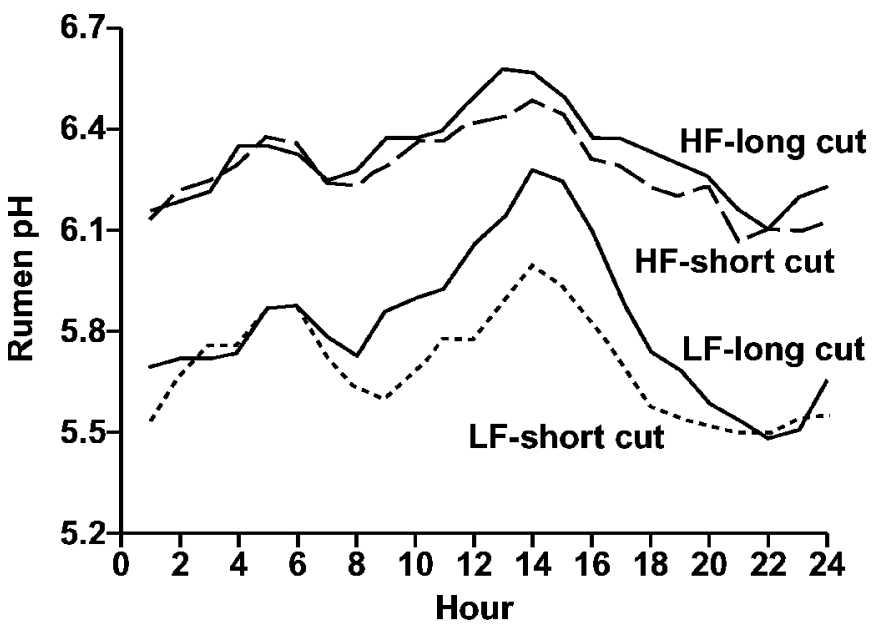

Figure 2. Effects of forage-to-concentrate ratio [low forage (LF), 35:65; high forage (HF), 60:40] and forage particle length (short and long cut) on diurnal variation of ruminal $\mathrm{pH}$. Feeding times were 0600,1500 , and $1800 \mathrm{~h}$.

which was slightly lower, and the high $\mathrm{F}$ :C-long AS diet, which was slightly higher.

One of the limitations of increasing peNDF through increased $\mathrm{F}: \mathrm{C}$ ratio is the negative effect on $\mathrm{DMI}$, which is caused by increased rumen fill (Allen, 2000). Lack of effect of FPL on DMI was due to the resulting particle length of the diets. In studies in which increasing peNDF lowered DMI, either a high-forage diet ( $>50 \%$;
Kononoff and Heinrichs, 2003a; Yansari et al., 2004) or very long FPL (TCL = 19 mm; Einarson et al., 2004) was used.

The increase in chewing activity, both rate (chews/ $\mathrm{kg}$ of DMI) and duration, when peNDF intake was increased through F:C ratio was expected (Kononoff and Heinrichs, 2003a). In other studies, total chewing time increased by $11 \%$ as NDF content of the diet increased from 31 to $37 \%$ (Beauchemin, 1991) or by $21 \%$ as the $\mathrm{NDF}$ content of the diet increased from 29 to $38 \%$ (Oba and Allen, 2000). Furthermore, the increase in chewing activity with increasing $\mathrm{F}: \mathrm{C}$ ratio was the resulting combination of increased ruminating and eating activities, which confirms results from our previous study (Yang et al., 2001b).

Increasing peNDF intake through FPL had inconsistent effects on chewing time, with only increased chewing activity (chews/kg of DMI and $\mathrm{min} / \mathrm{kg}$ of DMI) when diets were high in F:C ratio. The fact that FPL only promoted chewing in high-forage diets is somewhat surprising given that positive effects of FPL on chewing have been reported in cows fed diets with a wide range of F:C; from low (39:61; Krause et al., 2002) to high (69:31; Le Liboux and Peyraud, 1999). Increased chewing activity due to FPL with the high F:C diet was associated with the larger increase in peNDF $8.0 ; 1.5 \mathrm{~kg} /$ $\mathrm{d}$ more peNDF $\mathrm{N}_{8.0}$ with the high $\mathrm{F}: \mathrm{C}$ diet compared with only $0.7 \mathrm{~kg} / \mathrm{d}$ more with the low $\mathrm{F}: \mathrm{C}$ diet with increased FPL. Thus, low chewing time associated with very low

Table 6. Effects of forage-to-concentrate ratio (F:C) and forage particle length (FPL) on ruminal $\mathrm{pH}$ and fermentation $^{1}$

\begin{tabular}{|c|c|c|c|c|c|c|c|c|}
\hline \multirow[b]{3}{*}{ Item } & \multicolumn{4}{|c|}{$\mathrm{F}: \mathrm{C}$} & \multirow[b]{3}{*}{$\mathrm{SE}$} & \multirow{2}{*}{\multicolumn{3}{|c|}{ Effect }} \\
\hline & \multicolumn{2}{|c|}{$35: 65$} & \multicolumn{2}{|c|}{$60: 40$} & & & & \\
\hline & Short & Long & Short & Long & & $\mathrm{F}: \mathrm{C}$ & FPL & $\mathrm{F}: \mathrm{C} \times \mathrm{FPL}$ \\
\hline \multicolumn{9}{|l|}{$\mathrm{pH}$} \\
\hline Mean ruminal $\mathrm{pH}$ & 5.86 & 6.17 & 6.46 & 6.55 & 0.11 & 0.01 & 0.01 & $\mathrm{NS}^{2}$ \\
\hline Minimum daily $\mathrm{pH}$ & 5.26 & 5.36 & 5.78 & 5.86 & 0.08 & 0.01 & NS & NS \\
\hline Maximum daily $\mathrm{pH}$ & 6.32 & 6.47 & 6.64 & 6.72 & 0.09 & 0.01 & 0.02 & NS \\
\hline Area under $\mathrm{pH} 5.8, \mathrm{pH} \times \mathrm{h} / \mathrm{d}$ & 4.8 & 3.9 & 0.1 & 0.2 & 0.7 & 0.01 & NS & NS \\
\hline Area under $\mathrm{pH} 5.5, \mathrm{pH} \times \mathrm{h} / \mathrm{d}$ & 1.4 & 1.1 & 0.0 & 0.0 & 0.3 & 0.01 & NS & NS \\
\hline $\mathrm{pH}<5.8, \mathrm{~h} / \mathrm{d}$ & 11.5 & 10.1 & 1.1 & 1.3 & 1.9 & 0.01 & NS & NS \\
\hline $\mathrm{pH}<5.5, \mathrm{~h} / \mathrm{d}$ & 7.8 & 5.9 & 0.0 & 0.2 & 1.2 & 0.01 & 0.07 & NS \\
\hline \multicolumn{9}{|l|}{ VFA, $\mathrm{m} M$} \\
\hline $\begin{array}{l}\text { Total } \\
\mathrm{mol} / 100 \mathrm{~mol}\end{array}$ & 137.0 & 132.3 & 121.3 & 120.9 & 3.5 & 0.01 & NS & NS \\
\hline Acetate $(\mathrm{A})$ & 53.3 & 53.2 & 62.8 & 62.2 & 1.0 & 0.01 & NS & NS \\
\hline Propionate $(\mathrm{P})$ & 30.6 & 30.6 & 19.9 & 20.5 & 1.4 & 0.01 & NS & NS \\
\hline Butyrate & 11.9 & 11.8 & 12.2 & 12.1 & 1.0 & NS & NS & NS \\
\hline Branched-chain fatty acids ${ }^{3}$ & 2.0 & $\begin{array}{r}11.0 \\
2.2\end{array}$ & 2.8 & 3.1 & 0.1 & 0.01 & 0.09 & NS \\
\hline $\mathrm{A}: \mathrm{P}$ ratio & 1.83 & 1.81 & 3.19 & 3.07 & 0.14 & 0.01 & NS & NS \\
\hline $\mathrm{NH}_{3} \mathrm{~N}, \mathrm{~m} M$ & 8.5 & 8.5 & 11.4 & 12.8 & 0.9 & 0.01 & NS & NS \\
\hline
\end{tabular}

\footnotetext{
${ }^{1}$ Alfalfa forage was harvested at a theoretical chop length of 19.1 and $7.9 \mathrm{~mm}$ for long- and short-cut silages, respectively.

${ }^{2} \mathrm{NS}=P>0.10$.

${ }^{3}$ Isobutyrate + isovalerate.
} 
Table 7. Pearson correlation coefficients ${ }^{1}$ between physical and chemical measures of fiber and chewing activity, ruminal $\mathrm{pH}$, and fermentation

\begin{tabular}{|c|c|c|c|c|c|c|c|c|}
\hline \multirow[b]{2}{*}{$\underline{\text { Variables }}$} & \multicolumn{4}{|c|}{ Diet, ${ }^{2} \%$ of DM } & \multicolumn{4}{|c|}{ Forage, ${ }^{3} \mathrm{~kg} / \mathrm{d}$} \\
\hline & $19 \mathrm{~mm}$ & $\mathrm{NDF}$ & peNDF $_{8.0}$ & peNDF $_{1.18}$ & $19 \mathrm{~mm}$ & $\mathrm{NDF}$ & $\operatorname{peNDF}_{8.0}$ & peNDF $_{1.18}$ \\
\hline \multicolumn{9}{|l|}{ Eating } \\
\hline $\mathrm{min} / \mathrm{d}$ & 0.40 & 0.26 & 0.27 & 0.24 & 0.39 & 0.43 & 0.47 & 0.49 \\
\hline $\mathrm{min} / \mathrm{kg}$ of DMI & 0.52 & 0.01 & 0.54 & 0.55 & 0.20 & 0.54 & 0.58 & 0.62 \\
\hline \multicolumn{9}{|l|}{ Ruminating } \\
\hline $\mathrm{min} / \mathrm{d}$ & 0.56 & 0.09 & 0.54 & 0.37 & 0.05 & 0.41 & 0.39 & 0.37 \\
\hline $\mathrm{min} / \mathrm{kg}$ of $\mathrm{DMI}$ & 0.51 & -0.08 & 0.59 & 0.49 & -0.03 & 0.41 & 0.41 & 0.42 \\
\hline \multicolumn{9}{|l|}{ Total chewing } \\
\hline $\mathrm{min} / \mathrm{d}$ & 0.61 & 0.16 & 0.56 & 0.40 & 0.16 & 0.49 & 0.48 & 0.47 \\
\hline $\mathrm{min} / \mathrm{kg}$ of DMI & 0.54 & -0.07 & 0.61 & 0.53 & 0.02 & 0.47 & 0.47 & 0.49 \\
\hline $\mathrm{min} / \mathrm{kg}$ of $\mathrm{NDF}$ intake & 0.14 & -0.52 & -0.18 & -0.55 & -0.31 & -0.05 & -0.02 & -0.01 \\
\hline Mean ruminal pH & 0.78 & 0.41 & 0.73 & 0.36 & 0.41 & 0.88 & 0.84 & 0.85 \\
\hline Time $<\mathrm{pH} 5.8, \mathrm{~h} / \mathrm{d}$ & -0.53 & -0.15 & -0.46 & -0.09 & -0.18 & -0.75 & -0.76 & -0.80 \\
\hline Time $<\mathrm{pH} 5.5, \mathrm{~h} / \mathrm{d}$ & -0.57 & -0.12 & -0.45 & -0.05 & -0.10 & -0.76 & -0.77 & -0.80 \\
\hline Total VFA, mM & -0.57 & -0.31 & -0.50 & -0.27 & -0.17 & -0.70 & -0.69 & -0.72 \\
\hline Acetate, $\mathrm{mol} / 100 \mathrm{~mol}$ & 0.53 & 0.14 & 0.43 & 0.09 & -0.02 & 0.77 & 0.77 & 0.82 \\
\hline Propionate, $\mathrm{mol} / 100 \mathrm{~mol}$ & -0.49 & -0.14 & -0.41 & -0.09 & -0.01 & -0.75 & -0.75 & -0.81 \\
\hline
\end{tabular}

\footnotetext{
${ }^{1}$ Correlation coefficients were significant at $P<0.01$ ( $>0.62$ or $\left.<-0.62\right), P<0.05(>0.49$ or $<-0.49$ ), and $P<0.10(>0.43$ or $<-0.43)$.

${ }_{2}^{2} \mathrm{peNDF}_{8.0}$ and peNDF $_{1.18}=$ physically effective NDF determined as NDF content of TMR multiplied by pef $_{8.0}$ and pef $f_{1.18}$, respectively (Table 3).

${ }^{3} \mathrm{peNDF}_{8.0}$ and peNDF $\mathrm{N}_{1.18}=$ physically effective NDF determined as NDF content of alfalfa silage multiplied by pef $_{8.0}$ and pef p.18 $_{18}$, respectively (Table 1 ).
}

peNDF diets is not easily corrected by simply increasing FPL, because the overall increase in peNDF intake due to FPL alone is relatively small when the proportion of forage in the diet is low.

Furthermore, the increase in chewing time with increased FPL was solely due to increased ruminating activity. Similar observations have been reported for AS (Beauchemin et al., 2003), corn silage (Kononoff et al., 2003b), and barley silage (Yang and Beauchemin, 2006a), whereas other studies (Kononoff and Heinrichs, 2003a; Yansari et al., 2004) showed that both eating and ruminating activities were improved by increasing the particle length of alfalfa forage or corn silage. Whether increased chewing results from ruminating alone or from both eating and ruminating seems to depend on the final particle length of the diet. Diets with relatively long particle length reduce the ease of prehension and mastication, and therefore increase eating activity in addition to increasing ruminating activity (Kononoff and Heinrichs, 2003a; Yang and Beauchemin, 2006a). For example, De Boever et al. (1993) reported that eating time increased when the TCL of corn silage was increased from 8 to $16 \mathrm{~mm}$, whereas only ruminating time increased when the TCL of corn silage was increased from 4 to $8 \mathrm{~mm}$.

Eating time $(\mathrm{min} / \mathrm{kg}$ of DMI; $\mathrm{r}=0.54, P<0.04)$ and total chewing time $(\mathrm{min} / \mathrm{d} ; \mathrm{r}=0.49, P<0.05)$ were positively correlated to NDF intake from forage sources but not total NDF intake (Table 7), indicating that it is primarily the NDF from long particles that affects chewing. In fact, total chewing time $(\mathrm{min} / \mathrm{d})$ and eating and ruminating time ( $\mathrm{min} / \mathrm{kg}$ of DMI) were more highly correlated to the particles on the $19-\mathrm{mm}$ screen and dietary peNDF than to dietary NDF content (Table 7). A linear increase in chewing time ( $\mathrm{min} / \mathrm{d}$, Table 5; analysis not shown) in response to peNDF content of the diet (Table 3) was also detected. These results suggest that peNDF is a better predictor of chewing activity than particle length or NDF content alone because peNDF accounts for both particle length and NDF content. Previous studies report linear increases in chewing time with increasing dietary peNDF ${ }_{8.0}$ from 10.1, 12.0 , and 13.3 to $15.2 \%$ of DM for cows fed AS-based diets (Kononoff and Heinrichs, 2003a), or from 8.9 and 10.3 to $11.5 \%$ of DM for cows fed corn silage-based diets (Beauchemin and Yang, 2005).

There is a need for a system that provides a consistent indication of chewing activity for use in diet formulation. However, none of the current systems based on NDF or peNDF provides a completely satisfactory estimation of chewing activity (Yang and Beauchemin, 2006b; Zebeli et al., 2006) because chewing index (min/ $\mathrm{kg}$ of NDF or peNDF intake) is not constant over a range of intakes. In our study, chewing per kilogram of forage NDF intake varied from 135 to 204 (data not shown) whereas chewing index based on total NDF intake was fairly consistent across treatments, ranging from 101 to 110 (Table 5). However, Zebeli et al. (2006) reviewed 99 published treatment means and found that chewing index varied from 54 to $160 \mathrm{~min} / \mathrm{kg}$ of NDF 
intake, indicating that NDF intake does not reliably predict chewing duration. Chewing index based on intake of peNDF ( $\mathrm{min} / \mathrm{kg}$ of peNDF) was relatively constant among diets with peNDF 1.18 (114 to 127), but not with peNDF 8.0 (235 to 402). However, other studies report considerable variation in chewing index based on peNDF ${ }_{1.18}$, ranging from 71 to 644 for 87 published treatment means (Zebeli et al., 2006). Therefore, chewing time is generally increased with increasing NDF and peNDF content, but the amount of chewing per unit intake is inconsistent because it is affected by other factors such as fermentability of the diet (Krause et al., 2002).

Increased ruminal $\mathrm{pH}$ with increasing $\mathrm{F}: \mathrm{C}$ ratio was consistent with the decrease in ruminal VFA concentration and the increase in chewing activity. Ruminal $\mathrm{pH}$ reflects the balance between acid production in the rumen and acid removal through neutralization and absorption within the rumen. Feeding the high F:C diet would have reduced the rate of acid production in the rumen because less starch was fermented in the rumen compared with feeding the low F:C diet (our unpublished data). Furthermore, the smaller meal size and slower eating rate would have helped reduce the diurnal fluctuations in ruminal $\mathrm{pH}$. The increased chewing could have also contributed to increased buffering capacity within the rumen due to higher salivary secretion. Consequently, the extent of subacute ruminal acidosis was minimal for cows fed the high $\mathrm{F}: \mathrm{C}$ diet and extensive (i.e., more than $10 \mathrm{~h} / \mathrm{d}$ of $\mathrm{pH}<5.8$ ) for cows fed the low F:C diet even when FPL was increased.

Increasing peNDF intake through increased FPL increased the mean and maximum ruminal $\mathrm{pH}$, but the increase did not completely alleviate the acidosis in cows fed the low F:C diet. Despite similar peNDF intakes, the degree of acidosis was greater in cows fed low F:C-long AS than cows fed high F:C-short AS, indicating that increasing $\mathrm{F}: \mathrm{C}$ ratio is a more effective means of reducing acidosis than increasing forage chop length. Increasing FPL increases $\mathrm{pH}$ but the elevation in $\mathrm{pH}$ for cows fed a low $\mathrm{F}: \mathrm{C}$ ratio diet is not mediated through increased chewing, a change in meal patterns, or fermentability of the diet, as is the case with increased F:C ratio. Our study clearly demonstrates that the degree of acidosis in cows fed diets with similar peNDF levels but different $F: C$ ratios varies because the ruminal fermentability of feeds is not accounted for by the peNDF concept. Thus, formulating diets on the basis of peNDF without accounting for the fermentability of the diet may not totally eliminate acidosis when diets are rapidly fermented, as was the case in this study for the low F:C ratio diet. Thus, current recommendations for particle size distributions (Kononoff and Heinrichs, 2007) appear to be adequate for high-forage diets low in starch, but these recommendations will not eliminate subacute acidosis in cows fed low F:C diets.

When examined across all diets and both means of increasing peNDF intake, mean ruminal $\mathrm{pH}$ was highly $(P<0.01)$ correlated to intake of dietary particles retained on the $19-\mathrm{mm}$ sieve $(\mathrm{r}=0.78), \mathrm{peNDF}_{8.0}$ of the $\operatorname{diet}(\mathrm{r}=0.73)$, and intake of $\mathrm{peNDF}_{8.0}(\mathrm{r}=0.84)$ from forage sources (Table 7). The duration that $\mathrm{pH}$ remained below 5.8 was inversely correlated to the peNDF $_{8.0}$ of diet $(\mathrm{r}=-0.46, P<0.10)$ and intake of $\mathrm{peNDF}_{8.0}(\mathrm{r}=-0.77, P<0.01)$ from forage sources, indicating that increasing peNDF $_{8.0}$ intake reduced acidosis. However, the correlation between chewing and ruminal $\mathrm{pH}$ was not significant (data not shown). Therefore, increasing the intake of long forage particles and the intake of peNDF by feeding higher forage diets of longer chop length improves ruminal $\mathrm{pH}$, but the improvement is not necessarily due to increased chewing time. Long forage particles create a floating mat in the rumen that stimulates reticuloruminal contractions. Without these mixing motions the rumen becomes a less dynamic pool, and removal of VFA via absorption and fluid passage from the rumen declines, thereby increasing the risk of acidosis. Feeding longparticle fiber can also shift the site of starch digestion from the rumen to the intestine, which reduces the potential for ruminal acidosis (Yang and Beauchemin, 2006b).

Our results demonstrate the importance of forage $\mathrm{NDF}$ over total NDF for maintaining the ruminal $\mathrm{pH}$ within a healthy range. The correlation coefficient between mean ruminal $\mathrm{pH}$ and forage NDF content $(\mathrm{r}=$ $0.88, P<0.01$ ) was twice as high as for ruminal $\mathrm{pH}$ and total NDF ( $\mathrm{r}=0.41, P<0.11$; Table 7 ). The correlation for duration of $\mathrm{pH}$ below 5.8, an indication of the degree of acidosis, and total NDF was not significant, whereas its correlation with forage NDF $(\mathrm{r}=0.75, P<0.01)$ was high. Use of peNDF from forage sources further refines the prediction of acidosis. The correlation of dietary peNDF $_{8.0}$ with the duration of $\mathrm{pH}<5.8$ tended to be significant $(\mathrm{r}=0.46, P<0.07)$, but the correlation was much higher when forage peNDF $8.0(\mathrm{r}=0.76, P<0.01)$ was considered. These results confirm that forage NDF and peNDF, particularly peNDF from forage sources, are more reliable methods of formulating diets to prevent ruminal acidosis than total NDF content of the diet. For example, NRC (2001) recommends a minimum of $25 \% \mathrm{NDF}$ in the diet, with $75 \%$ of this fiber coming from forage sources (i.e., 19\% NDF from forages). The recommended amount of NDF from forage sources can be decreased to as low at $15 \%$ if total dietary NDF is increased and the NFC levels are lowered from 44 to $36 \%$. Although these recommendations help prevent 
ruminal acidosis, incorporating the peNDF system would result in further improvement.

\section{CONCLUSIONS}

The peNDF content of dairy cow diets was altered by changing the forage proportion or FPL, and ruminal acidosis was defined using a threshold $\mathrm{pH}$ value of 5.8, below which fiber digestion by the rumen bacteria is suboptimal. Increasing peNDF intake reduced ruminal acidosis; mean ruminal $\mathrm{pH}$ and the duration that $\mathrm{pH}$ remained below 5.8 were highly correlated to intake of long particles (those retained on the $19-\mathrm{mm}$ sieve of the Penn State Particle Separator), peNDF $_{8.0}$ of the diet, and intake of peNDF ${ }_{8.0}$ from forage sources. The reduction in rumen acidosis with increased peNDF intake was not directly related to increased chewing activity. Increasing the forage proportion increased chewing activity and reduced meal size, but increasing the FPL only increased chewing activity when high-forage diets were fed. Thus, the improvement of ruminal $\mathrm{pH}$ status with increased peNDF intake reflects a general improvement in the rumen environment.

This study shows that intake of dietary peNDF, particularly forage peNDF, is a good indicator of the ruminal $\mathrm{pH}$ status of dairy cows. Increasing forage proportion and the chop length of forages should be considered as strategies to reduce the risk of acidosis in dairy cows. However, for low-forage diets, the increase in peNDF intake resulting from increased FPL is relatively small, and thus is insufficient to fully alleviate subacute acidosis. In that case, increasing the forage proportion can be a very effective means of reducing the risk of acidosis.

\section{ACKNOWLEDGMENTS}

This experiment was financially supported by the Dairy Farmers of Canada (Ottawa, ON) and Agriculture and Agri-Food Canada's Matching Investment Initiative. The authors thank K. Andrews, B. Farr, A. Furtado, D. Vedres, and R. Wuerfel for their assistance in performing sampling and laboratory analyses, as well as the staff of the Lethbridge Research Centre dairy unit for care of the cows and milk sample collection.

\section{REFERENCES}

Allen, M. S. 2000. Effects of diet on short-term regulation of feed intake by lactating dairy cattle. J. Dairy Sci. 83:1598-1624.

AOAC. 1990. Official Methods of Analysis. Vol. I. 15th ed. Association of Official Analytical Chemists, Arlington, VA.

Beauchemin, K. A. 1991. Effects of dietary neutral detergent fiber concentration and alfalfa hay quality on chewing, rumen function, and milk production of dairy cows. J. Dairy Sci. 74:3140-3151.

Beauchemin, K. A., and W. Z. Yang. 2005. Effects of physically effective fiber on intake, chewing activity, and ruminal acidosis for dairy cows fed diets based on corn silage. J. Dairy Sci. 88:2117-2129.

Beauchemin, K. A., W. Z. Yang, and L. M. Rode. 2003. Effects of particle size of alfalfa-based dairy cow diets on chewing activity, rumen fermentation, and milk production. J. Dairy Sci. 86:630-643.

De Boever, J. L., D. L. De Brabander, A. M. DeSmet, J. M. Vanacker, and C. V. Boucque. 1993. Evaluation of physical structure. 2. Maize silage. J. Dairy Sci. 76:1624-1634.

DeVries, T. J., M. A. G. von Keyserlingk, D. M. Weary, and K. A. Beauchemin. 2003. Measuring the feeding behavior of lactating dairy cows in early to peak lactation. J. Dairy Sci. 86:3354-3361.

Einarson, M. S., J. C. Plaizier, and K. M. Wittenberg. 2004. Effects of barley silage chop length on productivity and rumen conditions of lactating dairy cows fed a total mixed ration. J. Dairy Sci. 87:2987-2996.

Kononoff, P. J., and A. J. Heinrichs. 2003a. The effect of reducing alfalfa haylage particle size on cows in early lactation. J. Dairy Sci. 86:1445-1457.

Kononoff, P. J., and A. J. Heinrichs. 2003b. The effect of corn silage particle size and cottonseed hulls on cows in early lactation. J. Dairy Sci. 86:2438-2451.

Kononoff, P. J., and A. J. Heinrichs. 2007. Evaluating particle size of forages and TMRs using the New Penn State Forage Particle Separator. Penn State, College of Agricultural Sciences, Cooperative Extension, DAS 02-42, http://www.vetmed.wsu.edu/coursesjmgay/documents/DAS02421.pdf Accessed Jan. 12, 2007.

Kononoff, P. J., A. J. Heinrichs, and D. R. Buckmaster. 2003a. Modification of Penn State forage and total mixed ration particle separator and the effects of moisture content on its measurements. J. Dairy Sci. 86:1858-1863.

Kononoff, P. J., A. J. Heinrichs, and H. A. Lehman. 2003b. The effect of corn silage particle size on eating behavior, chewing activities, and rumen fermentation in lactating dairy cows. J. Dairy Sci. 86:3343-3353.

Krause, K. M., D. K. Combs, and K. A. Beauchemin. 2002. Effects of forage particle size and grain fermentability in midlactation cows. II. Ruminal pH and chewing activity. J. Dairy Sci. 85:1947-1957.

Lammers, B. P., D. R. Buckmaster, and A. J. Heinrichs. 1996. A simple method for the analysis of particle sizes of forage and total mixed rations. J. Dairy Sci. 79:922-928.

Le Liboux, S., and J. L. Peyraud. 1999. Effect of forage particle size and feeding frequency on fermentation patterns and sites and extent of digestion in dairy cows fed mixed diets. Anim. Feed Sci. Technol. 76:297-319.

Mertens, D. R. 1997. Creating a system for meeting the fiber requirements of dairy cows. J. Dairy Sci. 80:1463-1481.

NRC. 2001. Nutrient Requirements of Dairy Cattle. 7th rev. ed. Natl. Acad. Sci., Washington, DC.

Nocek, J. E. 1997. Bovine acidosis: Implication on laminitis. J. Dairy Sci. 80:1005-1028.

Oba, M., and M. S. Allen. 2000. Effects of brown midrib 3 mutation in corn silage on productivity of dairy cows fed two concentrations of dietary neutral detergent fiber: 2 . Chewing activities. J. Dairy Sci. 83:1342-1349.

Owens, F. N., D. S. Secrist, W. J. Hill, and D. R. Gill. 1998. Acidosis in cattle: A review. J. Anim. Sci. 76:275-286.

Penner, G. B., K. A. Beauchemin, and T. Mutsvangwa. 2006. An evaluation of the accuracy and precision of a stand-alone submersible continuous ruminal pH measurement system. J. Dairy Sci. 89:2132-2140.

Plaizier, J. C., T. Garner, T. Droppo, and T. Whiting. 2004. Nutritional practices on Manitoba dairy farms. Can. J. Anim. Sci. 84:501-509.

Rode, L. M., W. Z. Yang, and K. A. Beauchemin. 1999. Fibrolytic enzyme supplements for dairy cows in early lactation. J. Dairy Sci. 82:2121-2126.

SAS Institute. 1996. SAS7 User's Guide: Statistics. Version 7 ed. SAS Inst., Inc., Cary, NC.

Van Soest, P. J., J. B. Robertson, and B. A. Lewis. 1991. Methods for dietary fiber, neutral detergent fiber and non-starch polysaccharide in relation to animal nutrition. J. Dairy Sci. 74:35833597 . 
Weatherburn, M. W. 1967. Phenol-hypochlorite reaction for determination of ammonia. Anal. Chem. 39:971-974.

Yang, W. Z., and K. A. Beauchemin. 2006a. Effects of physically effective fiber on chewing activity and rumen $\mathrm{pH}$ of dairy cows fed diets based on barley silage. J. Dairy Sci. 89:217-228.

Yang, W. Z., and K. A. Beauchemin. 2006b. Physically effective fiber: Method of determination and effects on chewing, ruminal acidosis, and digestion by dairy cows J. Dairy Sci. 89:2618-2633.

Yang, W. Z., K. A. Beauchemin, and L. M. Rode. 2001a. Effects of grain processing, forage to concentrate ratio, and forage particle size on rumen $\mathrm{pH}$ and digestion by dairy cows. J. Dairy Sci. 84:2203-2216.
Yang, W. Z., K. A. Beauchemin, and L. M. Rode. 2001b. Barley processing, forage:concentrate, and forage length effects on chewing and digesta passage in lactating cows. J. Dairy Sci. 84:2709-2720.

Yansari, A. T., R. Valizadeh, A. Naserian, D. A. Christensen, P. Yu, and F. E. Shahroodi. 2004. Effects of alfalfa particle size and specific gravity on chewing activity, digestibility, and performance of Holstein dairy cows. J. Dairy Sci. 87:3912-3924.

Zebeli, Q., M. Tafaj, H. Steingass, B. Metzler, and W. Drochner. 2006. Effects of physically effective fiber on digestive processes and milk fat content in early lactating dairy cows fed total mixed rations. J. Dairy Sci. 89:651-668. 